\title{
Editor's overview
}

With the publication of this issue, two volumes of $A P$ have been produced, thanks to the efforts of contributors, editorial board members, guest referees, the journals staff of Cambridge University Press in New York and my able clerical assistant, Jacqueline Erickson Kurzeja. Moreover, the pressures attendant upon the launching of a new journal, I am happy to say, are easing, due, in the main, to an increase in the number of publishable articles we have been receiving, although most of them have had to undergo various kinds of revision. The most common problems were: (1) failure to make explicit the basic research and theory underpinnings of a study; (2) failure to carefully proofread the manuscript; (3) incomplete information regarding subjects; (4) incomplete Materials and/or Procedure sections; (5) incorrect or incomplete data analyses; (6) failure to cite all of the relevant literature; (7) clarity of writing (e.g., failure to define terms); and (8) departures from the style and/or typing requirements of the journal. Under (3), we encountered failures to indicate, where appropriate: how the subjects were chosen; whether or not they were native monolingual speakers of the language of the study; how proficient they were in the second language of the study; first-language proficiency; the names of any tests used in subject selection; whether or not any of them were suffering from neurological, sensory or emotional disorders; educational background; etiology; socio-economic status; distribution of the sexes; and to supply, again, where appropriate: means and standard deviations (or ranges) for chronological and mental age.

\section{THE PRESENT ISSUE}

From the standpoint of hard laboratory science, some of the most sophisticated and elegant research in basic psycholinguistics has been carried out by investigators interested in the process of speech sound preception. Thus it is significant when the "armaments" of these investigators (i.e., their research instruments, research paradigms, data analysis procedures and findings) are applied to problems in applied psycholinguistics, as in the case of the present study by MacKain, Best and Strange of the "categorical perception of English $/ \mathrm{r} /$ and $/ \mathrm{l} /$ by Japanese bilinguals." This investigation, with its findings concerning the relationship between second-language experience and second-language speech sound perception, and their "implications for perceptual training of phonemic contrasts," goes a long way toward justifying applied psycholinguists' commitment to basic research and theory.

Phoneme-grapheme correspondences in reading in children at different developmental levels is the topic of the article by Mościcki and Tallal. The 
findings of this study suggest that systematic strategies underlie reading errors.

Research (see the reviews in Quigley \& King, 1980, and in Rosenberg in preparation) suggests that although typically delayed, the development of visual-manual counterparts of American English as well as the mastery of American English through the media of reading and writing in prelingually deaf children are, in the main, similar to the development of American English in normal hearing children. Past research on language development in prelingually deaf children, however, has concentrated on their implicit linguistic knowledge. The present study by Zorfass, on the other hand, explores, albeit in a preliminary way, prelingually deaf Signed English users' explicit linguistic knowledge or metalinguistic awareness. The deaf children Zorfass observed "exhibited varying metalinguistic abilities that generally increased with age and that were similar to the developmental pattern found in hearing populations." This study will doubtless form the basis for more detailed examinations of metalinguistic abilities in prelingually deaf children, including investigations of the relationship between implicit achievements in language development in, for example, the areas of sentence structure and grammatical morphology, and the development of metalinguistic awareness in these areas.

Although the subjects in the study by Connell and McReynolds of generalization in comprehension and production training were nonlanguage-disordered subjects, applications of their findings in the area of language intervention in language disordered children are likely to ensue. I make this prediction because of the many studies in the literature that indicate that the first-language acquisition strategies of language disordered children tend, for the most part, to be similar to those of non-languagedisordered children (Rosenberg, in preparation). Language intervention, however, as the reader will note when she or he examines Connell and McReynolds' study is not the only area for which its findings are relevant.

\section{GUEST REFEREES}

I would like to gratefully acknowledge the contributions of the following guest referees to the evaluation of a number of the manuscripts considered for publication in Volume 2 of the journal.

\begin{tabular}{|c|c|c|}
\hline $\begin{array}{l}\text { Rita Sloan Berndt } \\
\text { John Black } \\
\text { Marion Blank } \\
\text { Sheila E. Blumstein } \\
\text { Robert C. Calfee } \\
\text { Carol Chomsky } \\
\text { Arthur J. Compton } \\
\text { Phil J. Connell } \\
\text { Robert G. Curley } \\
\text { Philip S. Dale }\end{array}$ & $\begin{array}{l}\text { Mavis Donahue } \\
\text { Carol Fowler } \\
\text { R.C. Gardner } \\
\text { Fred Genesee } \\
\text { William S. Hall } \\
\text { Else Hamayan } \\
\text { Katherine S. Harris } \\
\text { Anthony Jorm } \\
\text { Wendy Martyna } \\
\text { Charley McCauley }\end{array}$ & $\begin{array}{l}\text { David J. McKirnan } \\
\text { Leija V. McReynolds } \\
\text { Paula Menyuk } \\
\text { Loraine K. Obler } \\
\text { Stephen P. Quigley } \\
\text { Ellen Bouchard Ryan } \\
\text { Jacqueline Sachs } \\
\text { Robert J. Scholes } \\
\text { Ronnie Wilbur } \\
\text { Patricia Wright } \\
\text { Edgar Zurif }\end{array}$ \\
\hline
\end{tabular}


Editor's overview

\section{ANNOUNCEMENT}

Starting with Volume 3,1982, the Editorial overview will no longer necessarily appear as a feature of every issue of the journal. This change will allow the Editor to eliminate the overview altogether when the relations between the articles in an issue are obvious or when the larger contexts of the individual articles are apparent from the articles themselves, and to comment on a larger sample of articles than are present in a single issue. Information on developments in the field of general interest and purely editorial matters, moreover, may be discussed at various times independently of the overview.

\section{REFERENCES}

Quigley, S. P., \& King, C. M. Syntactic performance of hearing impaired and normal hearing individuals. Applied Psycholinguistics, 1980, 1. 329-356.

Rosenberg, S. Disorders of first-language development: Trends in research and theory. In E. S. Gollin (Ed.), Malformations of development: Biological and psychological sources and consequences. New York: Academic Press, in preparation.

Chicago, Illinois

October, 1981 


\section{Call for book proposals for a}

new series...

\section{Cambridge Monographs and Texts in Applied Psycholinguistics}

General Editor: Sheldon Rosenberg, University of Illinois at Chicago Circle

The series will draw together monographs and texts by authors in all the applied psycholinguistics disciplines who approach applied problems from the vantage point of basic research and theory in psycholinguistics and cognitive psychology. It will include (1) monograph-length reports of original research; (2) monograph-length critical integrative reviews of research; (3) major theoretical monographs; (4) language intervention programs for language-disordered individuals; (5) language assessment programs; (6) high-quality texts; (7) carefully selected and edited collections of research and other articles including, possibly, occasional conference reports and symposia.

Specific problem areas of interest to the series . . .

- Language and communicative development and functioning in normal children, and language and communicative functioning in normal adults: reading; writing; learning from texts and lectures (and other modes of verbal presentation); second-language learning and bilingualism; dialect and social-class differences; the assessment of linguistic maturity and communicative competence; and the application of psycholinguistics to computer language design and the design of written and oral information (e.g. instructions) nonverbal communication (e.g., sign language, gestures).

- Language and communicative disorders in children and adults: delayed language development; adult aphasia; childhood aphasia; reading disorders; writing disorders; disorders of articulation, phonology, speech sound perception or fluency; autistic and childhood schizophrenic language; adult schizophrenic language; and disorders associated with mental retardation, environmental deprivation, motor impairment, specific learning disabilities other than reading and writing, sensory deficit (deafness, blindness), environmental deprivation, and senile dementia.

Address inquiries to the Series Editor at Department of Psychology

University of Illinols at Chicago Circle

Box 4348

Chicago, Illinois 60680

(312) 996-6643/48 475-0541 or to

Dr. Susan Milmoe

Cambridge University Press (800) 221-4512/3
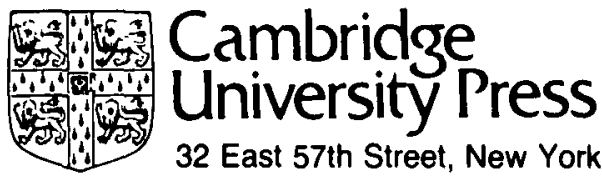

32 East 57th Street, New York, N.Y. 10022 